\title{
Absorption and Excretion of Cinepazide (Vasodilator) after Single and Multiple Oral Doses in Man
}

\author{
Jonosuke ATARASHI ${ }^{* 1}$. Norio TAKASUGI*2 Hisashi NOMURA*2 \\ Mamoru NOMURA*2 and Mitsuji SANO*2 \\ (Received on 30 December 1978) \\ *1 Department of Internal Medicine, Nippon Medical School, Tokyo \\ *2 Daiichi Seiyaku Co., Ltd., Research Institute, Tokyo
}

\begin{abstract}
Summary
The concentrations of cinepazide in human plasma and urine were studied by using high-performance liquid chromatography. Each of 7 healthy, male volunteers received 200 and $400 \mathrm{mg}$ of cinepazide on separate occasions for single dose experiments. In the case of the $200 \mathrm{mg}$ single dose, a rapid peak of plasma concentration at $2.8-4.9 \mu \mathrm{g} / \mathrm{ml}$ was observed at $1-3 \mathrm{hr}$, and $57.6 \%$ of the cinepazide was excreted in urine within $24 \mathrm{hr}$. The peak plasma level increased proportionally with the dose of cinepazide, whereas the extent of cinepazide excretion increased slightly with the dose.

In multiple dose experiments, each of these volunteers received, on two separate occasions, $200 \mathrm{mg}$ of cinepazide t. i. d. at $9: 00 \mathrm{am}, 1: 00 \mathrm{pm}$ and $5: 00 \mathrm{pm}$ each day for 1 day and 5 days, respectively. The results on the peak and valley plasma levels of multiple dose cinepazide indicated reproducible absorption in comparison with values predicted using a computer program describing a one compartment, open pharmacokinetic model. The extent of cumulative urinary excretion of cinepazide was nearly constant during multiple dose experiments. No side effects were noted.
\end{abstract}

Key Words : Cinepazide, Plasma concentration, Urinary excretion, Human pharmacokinetics, HPLC determination

*2 132 Minamifunabori-cho 2810, Edogawa-ku, Tokyo To Norio TAKASUGI reprints requests should be addressed. 
Cinepazide, 4-(3, 4, 5-trimethoxycinnamoyl) - 1 - (1 - pyrrolidinyl) carbonylmethylpiperazine maleate was developed by Delalande Co., Ltd. (France) as a vasodilator (Pourrias, B. et al., 1974a, Pourrias, B. et al., 1974b, Marmo, E. et al., 1973). The chemical structure is shown in Fig. 1. The compound was found to be the most active vasodilator of several substituted cinnamoylpiperazines (Fauran, C. et al., 1969, Huguet, G. et al., 1969). The drug has been used to treat peripheral and cerebral vascular disorders (Bremer, C., 1974, Garrigues, A., 1975). The metabolism of cinepazide in animals and human has been previously studied by Cameron, B. D. et al. (1976), Oliver, M. C. et al. (1977), Tsumura, M. et al. (1979) and Nomura, H. et al. (1979). Cameron, B. D. et al. (1976), showed that cinepazide $-{ }^{14} \mathrm{C}$ was absorbed well and that more than $60 \%$ of the radioactivity was excreted within $24 \mathrm{hr}$ in rats, dogs and man. For several hours more than $60 \%$ of the radioactivity in the plasma was due to the unchanged drug. Further, cinepazide was essentially excreted in urine, partly unchanged, in all three species. Olver, M.C. et al. (1977) studied the plasma level and urinary excretion of cinepazide in man. Less information could be available on the absorption and excretion of cinepazide after single and multiple oral doses in man. In the present study, the pharmacokinetics of cinepazide was studied in man after single and multiple oral doses by using high performance liquid chromatographic determination of the unchanged drug in the plasma and urine. The results of laboratory tests before and after drug administrations were also shown .

\section{Materials and Methods}

\section{Materials}

Cinepazide tablets (Daiichi Seiyaku Co., Ltd.) containing $200 \mathrm{mg}$ of cinepazide maleate were used.

\section{Volunteers}

Descriptions of the several healthy, male volunteers are shown in Table 1 . The subjects were confirmed to be submitted to the laboratory tests before and after drug administrations.

\section{Trial procedure}

Single oral dose : Seven volunteers took on separate occasions $200 \mathrm{mg}$ (Step 1) and $400 \mathrm{mg}$ (Step 2) of cinepazide with a small amount of water $30 \mathrm{~min}$ after a standard breakfast. Heparinized plasma specimens were obtained at 0 , $0.5,1,1.5,2,3,5,7$ and $24 \mathrm{hr}$ after drug ingestion. Urine collections were also carried out at 0, 2, 4, 6, 8 and $24 \mathrm{hr}$.

Multiple oral dose : Seven volunteers took

Table 1 Description of Volunteers ${ }^{a)}$

\begin{tabular}{c|c|c}
\hline Subject & Age (yrs) & Body weight $(\mathrm{kg})$ \\
\hline A & 38 & 61.0 \\
B & 41 & 61.5 \\
C & 42 & 62.0 \\
D & 31 & 59.0 \\
E & 36 & 59.5 \\
F & 29 & 55.5 \\
G & 32 & 61.7 \\
\hline
\end{tabular}

a) All were Japanese males.

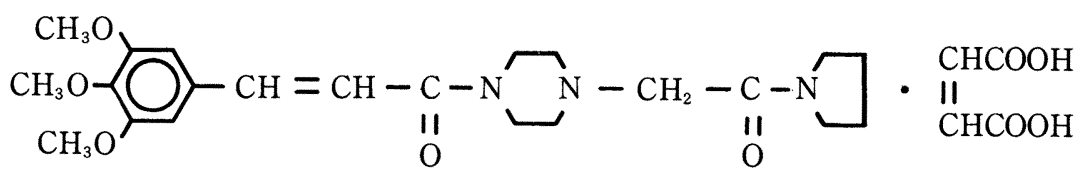

Fig. 1 Structure of cinepazide. 
Table 2-1 Clinical Values

\begin{tabular}{|c|c|c|c|c|c|c|c|c|c|c|c|c|}
\hline & \multicolumn{4}{|c|}{ Hematological test } & \multicolumn{7}{|c|}{ Serum biochemical test } \\
\hline & & $\begin{array}{c}\mathrm{RBC} \\
\left(\times 10^{6} / \mathrm{mm}^{3}\right)\end{array}$ & $\underset{(\mathrm{g} / \mathrm{dl})}{\mathrm{Hb}}$ & $\begin{array}{l}\mathrm{Ht} \\
(\%)\end{array}$ & $\begin{array}{c}\mathrm{WBC} \\
\left(\times 10^{3} / \mathrm{mm}^{3}\right)\end{array}$ & $\begin{array}{l}\text { GOT } \\
\text { (I.U.) }\end{array}$ & $\begin{array}{l}\text { GPT } \\
\text { (I.U.) }\end{array}$ & $\begin{array}{c}\text { ALP } \\
\text { (K.A.U.) }\end{array}$ & $\begin{array}{l}\mathrm{BUN} \\
(\mathrm{mg} / \mathrm{dl})\end{array}$ & $\begin{array}{c}\text { Crea } \\
(\mathrm{mg} / \mathrm{dl})\end{array}$ & $\begin{array}{c}\mathrm{Na}^{+} \\
(\mathrm{mEq} / \mathrm{l})\end{array}$ & $\left(\underset{\mathrm{mEq} / \mathrm{l})}{\mathrm{K}^{+}}\right.$ \\
\hline \multirow{5}{*}{ A } & 1 & 3.85 & 15.0 & 43.5 & 4.5 & 23 & 0 & 6.4 & 17.0 & 0.84 & 135 & 4.6 \\
\hline & 2 & 4.18 & 15.5 & 46.2 & 4.3 & 23 & 7 & 7.2 & 17.4 & 0.98 & 134 & 3.5 \\
\hline & 3 & 3.95 & 15.1 & 45.5 & 5.4 & 19 & 10 & 7.7 & 17.5 & 0.87 & 132 & 3.5 \\
\hline & 4 & 3.69 & 14.7 & 43.5 & 5.5 & 18 & 6 & 6.8 & 19.6 & 0.77 & 135 & 4.8 \\
\hline & 5 & 3.71 & 13.8 & 42.5 & 5.6 & 17 & 6 & 6.8 & 16.5 & 0.68 & 135 & 3.9 \\
\hline \multirow{5}{*}{ B } & 1 & 5.06 & 18.3 & 54.5 & 7.1 & 25 & 13 & 4.4 & 21.7 & 0.81 & 131 & 4.4 \\
\hline & 2 & 5.19 & 17.7 & 50.0 & 8.0 & 23 & 17 & 4.9 & 25.7 & 0.95 & 135 & 4.5 \\
\hline & 3 & 5.15 & 18.2 & 53.0 & 7.4 & 19 & 18 & 5.2 & 26.3 & 0.86 & 131 & 4.1 \\
\hline & 4 & 4.62 & 17.2 & 47.0 & 5.8 & 18 & 13 & 5.2 & 24.9 & 0.77 & 138 & 4.7 \\
\hline & 5 & 4.67 & 17.2 & 48.5 & 5.4 & 21 & 7 & 5.3 & 20.8 & 0.75 & 132 & 3.9 \\
\hline \multirow{5}{*}{$\mathrm{C}$} & 1 & 4.08 & 15.8 & 42.5 & 5.5 & 29 & 4 & 3.6 & 22.5 & 0.95 & 134 & 4.3 \\
\hline & 2 & 4.21 & 15.9 & 38.9 & 7.2 & 22 & 13 & 4.4 & 26.9 & 1.03 & 133 & 4.9 \\
\hline & 3 & 4.39 & 15.3 & 46.0 & 6.8 & 22 & 16 & 4.5 & 23.9 & 1.02 & 131 & 3.9 \\
\hline & 4 & 4.06 & 15.2 & 43.5 & 5.0 & 20 & 11 & 3.7 & 23.1 & 0.95 & 137 & 4.9 \\
\hline & 5 & 4.04 & 15.3 & 43.0 & 4.9 & 26 & 11 & 3.9 & 21.0 & 0.70 & 135 & 3.8 \\
\hline \multirow{5}{*}{ D } & 1 & 4.90 & 16.1 & 45.0 & 6.1 & 22 & 5 & 6.5 & 17.5 & 0.81 & 140 & 5.0 \\
\hline & 2 & 5.14 & 16.9 & 46.5 & 5.0 & 21 & 26 & 6.8 & 17.2 & 0.82 & 134 & 4.4 \\
\hline & 3 & 4.67 & 16.1 & 46.5 & 5.7 & 19 & 28 & 6.6 & 17.8 & 0.65 & 131 & 3.8 \\
\hline & 4 & 4.68 & 15.7 & 46.0 & 5.6 & 14 & 10 & 5.2 & 15.0 & 0.74 & 136 & 5.2 \\
\hline & 5 & 4.32 & 15.0 & 47.0 & 5.9 & 18 & 11 & 6.7 & 13.6 & 0.65 & 129 & 4.6 \\
\hline \multirow{5}{*}{$\mathrm{E}$} & 1 & 4.58 & 16.4 & 47.5 & 5.4 & 24 & 24 & 6.8 & 14.3 & 0.56 & 131 & 4.3 \\
\hline & 2 & 4.82 & 17.3 & 46.4 & 6.3 & 22 & 21 & 7.6 & 19.0 & 0.78 & 136 & 4.8 \\
\hline & 3 & 4.44 & 15.9 & 45.5 & 5.0 & 22 & 24 & 8.1 & 17.5 & 0.74 & 133 & 3.8 \\
\hline & 4 & 4.39 & 16.2 & 47.8 & 4.7 & 20 & 17 & 7.2 & 20.1 & 0.74 & 138 & 4.9 \\
\hline & 5 & 4.31 & 15.7 & 47.5 & 5.4 & 25 & 25 & 7.7 & 15.7 & 0.60 & 136 & 4.0 \\
\hline \multirow{5}{*}{$\mathrm{F}$} & 1 & 4.93 & 16.2 & 48.0 & 9.6 & 20 & 0 & 7.5 & 14.6 & 0.84 & 130 & 4.7 \\
\hline & 2 & 4.90 & 16.1 & 44.8 & 10.7 & 19 & 12 & 9.8 & 14.9 & 1.53 & 135 & 4.9 \\
\hline & 3 & 4.86 & 16.3 & 49.0 & 7.0 & 15 & 11 & 8.4 & 22.0 & 1.23 & 133 & 3.5 \\
\hline & 4 & 4.86 & 16.0 & 48.0 & 9.0 & 16 & 10 & 6.7 & 15.8 & 1.08 & 138 & 4.8 \\
\hline & 5 & 4.57 & 15.4 & 46.5 & 8.3 & 17 & 7 & 6.6 & 15.1 & 0.65 & 137 & 4.0 \\
\hline \multirow{5}{*}{$\mathrm{G}$} & 1 & 5.18 & 16.9 & 45.0 & 4.6 & 18 & 11 & 4.2 & 13.1 & 0.67 & 131 & 4.0 \\
\hline & 2 & 5.16 & 17.9 & 48.4 & 5.9 & 28 & 17 & 4.6 & 14.6 & 0.76 & 134 & 4.7 \\
\hline & 3 & 4.60 & 16.5 & 45.5 & 3.8 & 15 & 18 & 6.6 & 17.1 & 0.77 & 132 & 4.1 \\
\hline & 4 & 4.77 & 16.0 & 46.0 & 4.6 & 18 & 15 & 4.3 & 13.9 & 0.67 & 134 & 5.0 \\
\hline & 5 & 4.33 & 15.7 & 44.0 & 3.9 & 17 & 13 & 4.4 & 14.9 & 0.56 & 134 & 3.9 \\
\hline
\end{tabular}

$1:$ before step I , $2:$ after step I , $3:$ after step II , $4:$ after step III , $5:$ after step IV

meals at $8: 30,12: 30$, and $16: 30$ and received a tablet containing $200 \mathrm{mg}$ of cinepazide $30 \mathrm{~min}$ after each meal for 1 day (Step 3). Heparinized plasma specimens were obtained at $1.5,8,9,9.5$,
10,24 , and $32 \mathrm{hr}$ after the first administration, and urine was also collected at $0,4,8,24$, and 32 hr.

A similar protocol was followed when cine- 
Table 2-2 Clinical Values (Continued)

\begin{tabular}{|c|c|c|c|c|c|c|c|c|c|c|c|c|}
\hline & \multicolumn{3}{|c|}{ Serum biochemical test } & \multicolumn{5}{|c|}{ Urinalysis } & \multirow{2}{*}{$\mathrm{BP}$} & \multirow{2}{*}{ HR } & \multirow{2}{*}{ ECG } \\
\hline & & $\mid \begin{array}{c}\mathrm{Cl}^{-} \\
(\mathrm{mEq} / \mathrm{l})\end{array}$ & $\underset{(\mathrm{mg} / \mathrm{dl})}{\mathrm{CHO}}$ & $\underset{(\mathrm{g} / \mathrm{dl})}{\mathrm{TP}}$ & $\mathrm{PH}$ & Protein & Glucose & $\begin{array}{l}\text { Urobili- } \\
\text { nogen }\end{array}$ & Sediments & & & \\
\hline \multirow{5}{*}{ A } & 1 & 105.8 & 215 & 7.06 & 6.0 & $\operatorname{Tr}$. & - & \pm & O.B. & $140 / 74$ & 56 & O.B. \\
\hline & 2 & 96.6 & 208 & 7.12 & 6.5 & $\operatorname{Tr}$ & - & + & O.B. & $150 / 90$ & 58 & O.B. \\
\hline & 3 & 96.9 & 213 & 7.28 & 5.5 & + & - & + & O.B. & $142 / 88$ & 76 & O.B. \\
\hline & 4 & 102.6 & 212 & 6.90 & 5.5 & - & - & \pm & O.B. & $136 / 94$ & 55 & O.B. \\
\hline & 5 & 102.1 & 177 & 6.74 & 5.5 & Tr. & - & + & O.B. & $134 / 88$ & 50 & O.B. \\
\hline \multirow{5}{*}{ B } & 1 & 99.8 & 230 & 6.81 & 6.5 & - & - & \pm & O.B. & $134 / 90$ & 90 & O.B. \\
\hline & 2 & 94.8 & 221 & 6.40 & 6.0 & Tr. & - & \pm & O.B. & $124 / 86$ & 82 & O.B. \\
\hline & 3 & 100.3 & 237 & 6.65 & 5.5 & - & - & \pm & O.B. & $130 / 80$ & 88 & O.B. \\
\hline & 4 & 103.7 & 197 & 5.99 & 6.0 & - & - & \pm & O.B. & $126 / 94$ & 74 & O.B. \\
\hline & 5 & 101.9 & 184 & 6.13 & 5.5 & - & - & \pm & O.B. & $106 / 80$ & 76 & O.B. \\
\hline \multirow{5}{*}{$\mathrm{C}$} & 1 & 107.3 & 199 & 6.96 & 5.5 & Tr. & - & \pm & O.B. & $128 / 90$ & 57 & O.B. \\
\hline & 2 & 93.9 & 198 & 6.99 & 6.0 & - & - & \pm & O.B. & $126 / 90$ & 54 & O.B. \\
\hline & 3 & 95.8 & 203 & 7.25 & 6.5 & - & - & \pm & O.B. & $124 / 90$ & 62 & O.B. \\
\hline & 4 & 101.7 & 199 & 7.02 & 7.5 & Tr. & - & + & O.B. & $128 / 82$ & 52 & O.B. \\
\hline & 5 & 100.1 & 171 & 6.90 & 6.0 & - & - & \pm & O.B. & $118 / 82$ & 53 & O.B. \\
\hline \multirow{5}{*}{$\mathrm{D}$} & 1 & 99.8 & 249 & 6.98 & 5.5 & - & - & \pm & O.B. & $114 / 72$ & 51 & O.B. \\
\hline & 2 & 96.3 & 201 & 6.88 & 6.0 & Tr. & - & \pm & O.B. & $108 / 70$ & 47 & O.B. \\
\hline & 3 & 97.7 & 236 & 7.07 & 5.5 & Tr. & - & \pm & O.B. & $118 / 70$ & 56 & O.B. \\
\hline & 4 & 98.5 & 229 & 6.57 & 5.5 & - & - & \pm & O.B. & $112 / 70$ & 53 & O.B. \\
\hline & 5 & 94.3 & 193 & 6.93 & 6.0 & - & - & \pm & O.B. & $110 / 71$ & 52 & O.B. \\
\hline \multirow{5}{*}{$\mathrm{E}$} & 1 & 103.2 & 143 & 7.66 & 5.0 & Tr. & - & \pm & O.B. & $124 / 86$ & 58 & O.B. \\
\hline & 2 & 97.0 & 131 & 7.78 & 6.0 & - & - & \pm & O.B. & $118 / 82$ & 55 & O.B. \\
\hline & 3 & 96.9 & 143 & 7.31 & 5.5 & - & - & \pm & O.B. & $124 / 80$ & 46 & O.B. \\
\hline & 4 & 102.6 & 139 & 6.97 & 5.5 & - & - & \pm & O.B. & $140 / 88$ & 55 & O.B. \\
\hline & 5 & 103.8 & 121 & 6.94 & 6.0 & - & - & \pm & O.B. & $126 / 84$ & 54 & O.B. \\
\hline \multirow{5}{*}{$\mathrm{F}$} & 1 & 107.1 & 201 & 6.86 & 5.5 & Tr. & - & \pm & O.B. & $110 / 78$ & 70 & O.B. \\
\hline & 2 & 97.8 & 174 & 6.65 & 6.0 & Tr. & - & \pm & O.B. & $118 / 68$ & 58 & O.B. \\
\hline & 3 & 99.4 & 194 & 6.85 & 5.5 & Tr. & - & \pm & O.B. & $108 / 61$ & 62 & O.B. \\
\hline & 4 & 102.1 & 186 & 6.52 & 5.5 & Tr. & - & \pm & O.B. & $108 / 74$ & 70 & O.B. \\
\hline & 5 & 102.9 & 172 & 6.45 & 5.5 & Tr. & - & + & O.B. & $114 / 72$ & 68 & O.B. \\
\hline \multirow{5}{*}{$\mathrm{G}$} & 1 & 103.6 & 202 & 7.34 & 6.0 & - & - & \pm & O.B. & $124 / 88$ & 81 & O.B. \\
\hline & 2 & 96.8 & 148 & 7.21 & 6.0 & - & - & \pm & O.B. & $100 / 62$ & 58 & O.B. \\
\hline & 3 & 96.8 & 168 & 7.06 & 5.5 & - & - & \pm & O.B. & $112 / 74$ & 62 & O.B. \\
\hline & 4 & 95.4 & 165 & 6.98 & 5.5 & - & - & \pm & O.B. & $112 / 74$ & 67 & O.B. \\
\hline & 5 & 102.1 & 145 & 6.95 & 6.0 & - & - & \pm & O.B. & $118 / 78$ & 66 & O.B. \\
\hline
\end{tabular}

pazide was administered t. i. d. for 5 days (Step Samples were taken at 0, 1.5, 8, 9.5, 10 and $11 \mathrm{hr}$ 4). Heparinized plasma specimens were obtai- on day 5 and at 0 and $8 \mathrm{hr}$ on day 6 . Total urine ned at $0,1.5,8$ and $9.5 \mathrm{hr}$ after the first admi- was collected every $24 \mathrm{hr}$ for 5 days, and then nistration of the drug on days $1,2,3$, and 4 . at $8 \mathrm{hr}$ on day 6 . Samples were stored at $-20^{\circ}$ 
until analysis.

\section{Analytical methods}

Sample preparation

Plasma : To a $50 \mathrm{ml}$ glass stoppered centrifuge tube were added $1.0 \mathrm{ml}$ of plasma and $1 \mathrm{ml}$ of $\mathrm{M} / 15$ phosphate buffer solution ( $\mathrm{pH}$ 7.3). The samples were extracted with $10 \mathrm{ml}$ of chloroform containing $1 \mu \mathrm{g} / \mathrm{ml}$ of $\alpha$-naphthol, the internal stardard. An $8 \mathrm{ml}$ aliquot-of-chloroform layer was transferred to a $10 \mathrm{ml}$ glassstoppered centrifuge tube and evaporated to dryness under a stream of dry nitrogen. The residue was dissolved in $200 \mu \mathrm{l}$ of $0.01 \mathrm{~N}-\mathrm{HCl}-$ methanol $(50 / 50, \mathrm{v} / \mathrm{v})$ and $10 \mu \mathrm{l}$ was then subjected to high-performance liquid chromatography.

Urine : Urine samples were diluted 5-40 fold with water, if necessary. To a $50 \mathrm{ml}$ glassstoppered centrifuge tube were added $1.0 \mathrm{ml}$ of diluted urine and $1 \mathrm{ml}$ of $\mathrm{M} / 15$ phosphate buffer (pH 7.3). The samples were extracted with 10 $\mathrm{ml}$ of chloroform containing $10 \mu \mathrm{g} / \mathrm{ml}$ of $\alpha^{-}$ naphthol, the internal standard. A $5 \mathrm{ml}$ aliquot -of-chloroform layer was transferred to a 10 $\mathrm{ml}$ glass-stoppered centrifuge tube and evaporated to dryness under a stream of dry nitrogen. The residue was dissolved in $1 \mathrm{ml}$ of 0.04 $\mathrm{N}-\mathrm{HCl}-$ methanol $(50 / 50, \mathrm{v} / \mathrm{v})$ and $10 \mu \mathrm{l}$ was then subjected to high-performance liquid chromatography.

High performance liquid chromatography : A Hitachi 635 liquid chromatograph was used for analyzing of all samples. A stable reversed -phase stationary phase, Lichrosorb RP-18 ( 5 $\mu \mathrm{m}$ diameter, Merck), was packed into a $150 \times$ $2.1 \mathrm{~mm}$ i. d. stainless steel column using a balance density slurry. The mobile phase was $0.1 \%$ $\left(\mathrm{NH}_{4}\right)_{2} \mathrm{CO}_{3}$-methanol $(50 / 50, \mathrm{v} / \mathrm{v})$. The operating temperature was ambient and the flow rate of the eluate was $0.3 \mathrm{ml} / \mathrm{min}$. The effluent was monitored continuously at $305 \mathrm{~nm}$, with a full scale deflection of $0.02-0.08$ AUFS. Concentrations of unknown plasma and urine samples were calculated by comparing the peak height ratio of the extracted samples to processed standards. This method was found to be practical for determining unchanged cinepazide in plasma or urine. The performance of the assay is summarized in Table 3.

\section{Pharmacokinetic Analysis}

The plasma level versus time profile for cinepazide could be described adequately by viewing the body as consisting of one compartment, with the drug being absorbed, distributed and eliminated from the body through a series of first-order process. Fitting a double-expo-

Table 3 Performance Characteristics of the HPLC Assay

\begin{tabular}{c|c|c}
\hline \multirow{2}{*}{ Feature } & \multicolumn{2}{|c}{ Capability } \\
\hline \multirow{2}{*}{ applicability } & \multicolumn{2}{|c}{ cinepazide in human plasma and urine } \\
\cline { 2 - 3 } & plasma & urine \\
\hline efficiency & $102.0 \% \mathrm{recovery}$ & $102.6 \% \mathrm{recovery}$ \\
\hline precision & $\begin{array}{c} \pm 0.27 \mu \mathrm{g} / \mathrm{ml} \mathrm{S.D.} \\
(5 \mu \mathrm{g} / \mathrm{ml} \mathrm{plasma})\end{array}$ & $\begin{array}{c} \pm 1.96 \mu \mathrm{g} / \mathrm{ml} \mathrm{S} . \mathrm{D} . \\
(50 \mu / \mathrm{ml} \text { urine })\end{array}$ \\
\hline range & $0 \sim 10 \mu \mathrm{g} / \mathrm{ml}$ & $0 \sim 100 \mu \mathrm{g} / \mathrm{ml}$ \\
\hline specificity & \multicolumn{2}{|c}{ separates known metabolites } \\
\hline assay time & \multicolumn{2}{c}{ up to 30 samples per day manually } \\
\hline
\end{tabular}


nential curve to observed cinepazide concentrations in plasma was carried out by using the modification program of Lowenthal, W. et al. (1967).

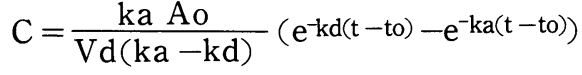

$$
\begin{aligned}
& \mathrm{C} \text { : plasma concentration at time } \mathrm{t}(\mu \mathrm{g} / \mathrm{ml}) \\
& \text { Ao : dose }(\mathrm{mg} / \mathrm{kg}) \\
& \mathrm{Vd} \text { : apparent volume of distribution }(\mathrm{l} / \mathrm{kg}) \\
& \mathrm{ka} \text { : absorption rate constant }\left(\mathrm{hr}^{-1}\right) \\
& \mathrm{kd} \text { : disappearance rate constant }\left(\mathrm{hr}^{-1}\right) \\
& \mathrm{t} \text { : time after drug administration (hr) } \\
& \text { to : lag time for absorption (hr) }
\end{aligned}
$$

Prediction of plasma levels after a given number of doses was carried out according to the assumption that the rate constant for absorption and disappearance is the same as that following the single dose for each dose of the multiple-dose regimen. The physiological characteristics of individuals are such that cinepazide concentrations at any given time are not normally distributed. Consequently, the median of a group may be a better choice than the mean for the simulation of plasma levels $(\mathrm{Mu}$ eller, F. W. et al., 1969).

\section{Results}

Cinepazide was administered in single 200 or $400 \mathrm{mg}$ oral doses. The peak concentration was obtained at 1-3 $\mathrm{hr}$ and averaged 3.7 (range 2.8 -4.9)and 8.1 (range 6.4-10.3) $\mu \mathrm{g} / \mathrm{ml}$, respectively (Table 4, Table 5). Interindividual variation in plasma level was rather large at $0.5-1 \mathrm{hr}$ after drug ingestion. The peak plasma level increased proportionally with the dose of cinepazide. Next, there was a rapid fall in the plasma level at both dose levels. The biological half-life varied from subject to subject over the range $0.9-2.7 \mathrm{hr}$ and was independent of the dose, as shown in Table 6.

The plasma levels were not measurable by the assay method after $24 \mathrm{hr}$ with the $200 \mathrm{mg}$ dose. The mean plasma level at $24 \mathrm{hr}$ was 0.02 $\mu \mathrm{g} / \mathrm{ml}$ following the $400 \mathrm{mg}$ oral dose. Urinary excretion after 200 and $400 \mathrm{mg}$ of cinepazide is shown in Fig. 2. Approximately 54 to $64 \%$ (mean $57.6 \%$ ) of the $200 \mathrm{mg}$ dose was excreted in urine within $24 \mathrm{hr}$, and 62 to $76 \%$ (mean 66.8 $\%$ ) of the $400 \mathrm{mg}$ dose was excreted in urine within $24 \mathrm{hr}$. The extent of urinary excretion increased slightly with the dose. Fig. 3 shows the relationship between the plasma level of

Table 4 Plasma Levels of Unchanged Cinepazide after Single Oral Administration of $200 \mathrm{mg}$ of Cinepazide to Human Subjects

\begin{tabular}{c|c|c|c|c|c|c|c|c}
\hline \multirow{2}{*}{ Subject } & \multicolumn{8}{|c}{ Plasma level $(\mu \mathrm{g} / \mathrm{ml})$} \\
\cline { 2 - 9 } & 0.5 & 1.0 & 1.5 & 2.0 & 3.0 & 5.0 & 7.0 & $24.0(\mathrm{hr})$ \\
\hline $\mathrm{A}$ & 0.2 & 1.8 & 2.6 & 2.9 & 2.3 & 1.0 & 0.4 & 0.0 \\
$\mathrm{~B}$ & 0.1 & 4.9 & 4.3 & 3.5 & 2.4 & 1.0 & 0.5 & 0.0 \\
$\mathrm{C}$ & 1.2 & 4.4 & 3.5 & 2.9 & 2.0 & 0.9 & 0.4 & 0.0 \\
$\mathrm{D}$ & 2.7 & 3.4 & 3.5 & 3.7 & 2.9 & 1.3 & 0.6 & 0.0 \\
$\mathrm{E}$ & 0.4 & 3.5 & 3.7 & 3.5 & 2.5 & 1.3 & 0.5 & 0.0 \\
$\mathrm{~F}$ & 0.4 & 2.8 & 2.7 & 2.6 & 2.5 & 1.1 & 0.6 & 0.0 \\
$\mathrm{G}$ & 0.1 & 1.3 & 2.5 & 3.0 & 3.5 & 1.2 & 0.5 & 0.0 \\
\hline Mean & 0.73 & 3.16 & 3.26 & 3.16 & 2.59 & 1.11 & 0.50 & 0.0 \\
\pm S.E. & \pm 0.36 & \pm 0.49 & \pm 0.25 & \pm 0.15 & \pm 0.18 & \pm 0.06 & \pm 0.03 &. \\
\hline
\end{tabular}


Table 5 Plasma Levels of Unchanged Cinepazide after Single Oral Administration of $400 \mathrm{mg}$ of Cinepazide to Human Subjects

\begin{tabular}{c|c|c|c|c|c|c|c|c}
\hline \multirow{2}{*}{ Subject } & \multicolumn{7}{|c}{ Plasma level $(\mu \mathrm{g} / \mathrm{ml})$} \\
\cline { 2 - 8 } & 0.5 & 1.0 & 1.5 & 2.0 & 3.0 & 5.0 & 7.0 & $24.0(\mathrm{hr})$ \\
\hline $\mathrm{A}$ & 4.5 & 7.1 & 7.0 & 6.8 & 5.2 & 2.2 & 0.9 & 0.0 \\
$\mathrm{~B}$ & 0.1 & 0.5 & 8.2 & 8.6 & 6.2 & 2.6 & 1.1 & 0.03 \\
$\mathrm{C}$ & 0.0 & 1.2 & 2.7 & 5.8 & 7.0 & 3.5 & 1.6 & 0.06 \\
$\mathrm{D}$ & 2.3 & 8.4 & 8.5 & 8.4 & 7.7 & 3.9 & 1.5 & 0.0 \\
$\mathrm{E}$ & 0.5 & 0.6 & 6.4 & 5.9 & 6.2 & 3.9 & 2.1 & 0.06 \\
$\mathrm{~F}$ & 7.0 & 9.1 & 7.7 & 6.5 & 5.1 & 2.5 & 1.0 & 0.0 \\
$\mathrm{G}$ & 2.6 & 10.3 & 9.3 & 6.1 & 6.2 & 2.9 & 1.1 & 0.0 \\
\hline Mean & 2.43 & 5.31 & 7.11 & 6.87 & 6.23 & 3.07 & 1.33 & 0.02 \\
$\pm \mathrm{S} . \mathrm{E}$. & \pm 0.98 & \pm 1.65 & \pm 0.82 & \pm 0.44 & \pm 0.35 & \pm 0.26 & \pm 0.16 & \pm 0.01 \\
\hline
\end{tabular}

Table 6 Parameters for Cinepazide Pharmacokinetics

\begin{tabular}{l|l|l|l|l|l|l|l|l|c}
\hline & A & B & C & D & E & F & G & mean & $\begin{array}{l}\text { fit to } \\
\text { medians }\end{array}$ \\
\hline $\mathrm{Ka}\left(\mathrm{hr}^{-1}\right)$ & 0.715 & 1.585 & 1.255 & 0.756 & 1.070 & 0.800 & 0.715 & 0.985 & 1.120 \\
$\mathrm{Kd}\left(\mathrm{hr}^{-1}\right)$ & 0.704 & 0.753 & 0.590 & 0.617 & 0.605 & 0.616 & 0.699 & 0.655 & 0.594 \\
$\mathrm{t} / 2(\mathrm{hr})$ & 0.98 & 0.92 & 1.17 & 1.12 & 1.15 & 1.13 & 0.99 & 1.07 & 1.17 \\
$\mathrm{t}_{0}(\mathrm{hr})$ & 0.42 & 0.50 & 0.25 & 0.00 & 0.42 & 0.42 & 0.83 & 0.41 & 0.42 \\
\hline
\end{tabular}

\begin{tabular}{l|l|l|l|l|l|l|l|l|r}
\hline & A & B & C & D & E & F & G & mean & $\begin{array}{l}\text { fit to } \\
\text { medians }\end{array}$ \\
\hline $\mathrm{Ka}\left(\mathrm{hr}^{-1}\right)$ & 0.785 & 1.870 & 0.915 & 0.731 & 1.973 & 1.291 & 1.251 & 1.259 & 0.726 \\
$\mathrm{Kd}\left(\mathrm{hr}^{-1}\right)$ & 0.663 & 0.362 & 0.278 & 0.702 & 0.255 & 0.582 & 0.608 & 0.493 & 0.708 \\
$\mathrm{t} 1 / 2(\mathrm{hr})$ & 1.05 & 1.91 & 2.49 & 0.99 & 2.72 & 1.19 & 1.14 & 1.64 & 0.98 \\
$\mathrm{t}_{0}(\mathrm{hr})$ & 0.08 & 0.92 & 0.83 & 0.33 & 0.92 & 0.08 & 0.33 & 0.50 & 0.33 \\
\hline
\end{tabular}

cinepazide and the urinary excretion rate. The experimental results here show that the urinary excretion rate of unchanged cinepazide is directly proportional to the plasma level of cinepazide in human volunteers. Fig. 4 shows the plasma levels of unchanged cinepazide after 1 day of multiple oral administration (t. i. d. $200 \mathrm{mg}$ ). The individual plasma levels at $7: 00 \mathrm{pm}(2 \mathrm{hr}$ after the $3 \mathrm{rd}$ administration) were $2.6 \sim 5.6 \mu \mathrm{g} /$ $\mathrm{ml}$ (mean $4.6 \mu \mathrm{g} / \mathrm{ml}$ ). This mean plasma level was slightly higher than the peak plasma level after a single oral dose of $200 \mathrm{mg}$ of cinepazide. At $24 \mathrm{hr}$ after the final dose, the plasma cinepazide levels were nearly zero. Table 7 shows the result of urinary excretion of unchanged cinepazide following 1 day of multiple oral doses (t. i. d. $200 \mathrm{mg}$ ).

Approximately 41 to $69 \%$ (mean $53.5 \%$ ) of the dose was excreted in urine over $24 \mathrm{hr}$ after the initial administration. In comparison with the urinary excretion after a single oral dose, a nearly equal percentage of the unchanged drug 


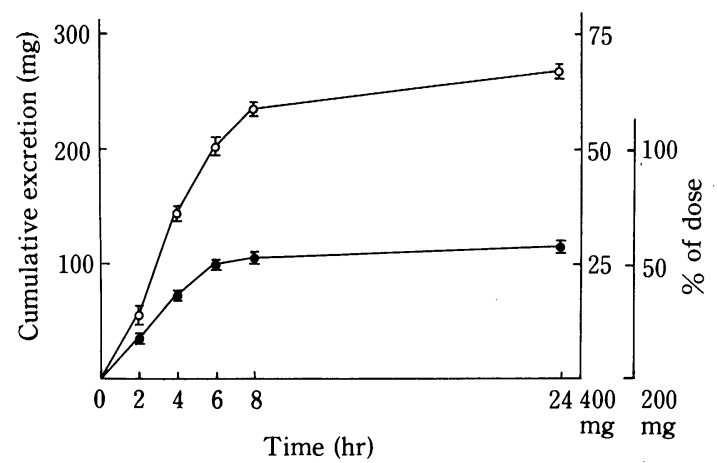

Fig. 2 Mean cumulative urinary excretion of unchanged cinepazide after single oral administrations.

- : $200 \mathrm{mg} / \mathrm{man},-\mathrm{O}-\mathrm{:}: 400 \mathrm{mg} / \mathrm{man}$ Mean values \pm S. E. are given.

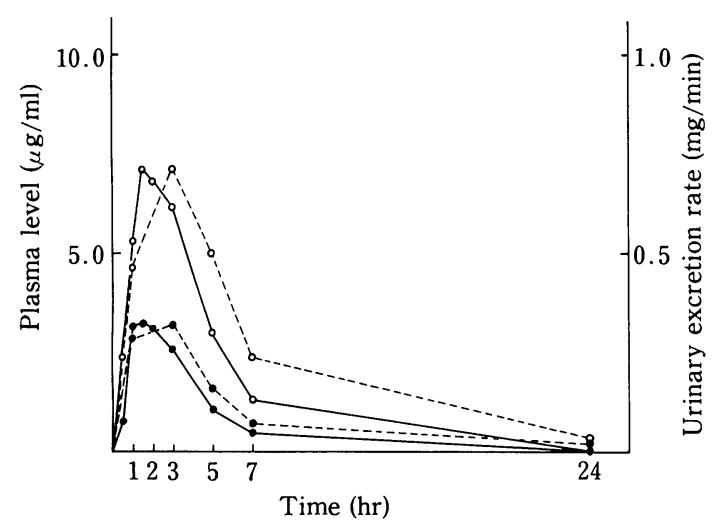

Fig. 3 Plasma levels and urinary excretion rates of unchanged cinepazide after a single oral administration. $200 \mathrm{mg} / \mathrm{man}$ (-): plasma level.: urinary excretion rate), $400 \mathrm{mg} /$ man (-O-: plasma level,-- $\bigcirc-$ : urinary excretion rate)

was excreted. Fig. 5 shows the plasma levels of unchanged cinepazide following multiple oral administration (t.i.d. $200 \mathrm{mg}$ ) for five days. The daily peak and valley plasma cinepazide level profile coincided with that of the 1-day multiple dosing. Table 8 shows the urinary excretion of unchanged cinepazide following 5 days of multiple oral administration (t. i. d. 200

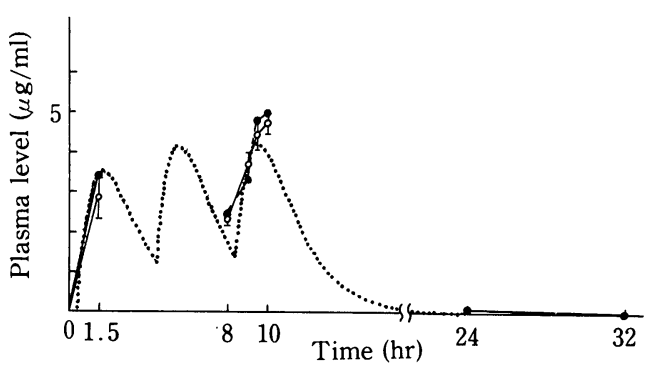

Fig. 4 Plasma level of unchanged cinepazide during and after multiple oral administration to human subjects (200 mg, t. i. d., for one day). Dotted line for one-compartment open model fit to medians. $\Phi:$ mean value \pm S. E., : median

mg). The extent of the cumulative urinary excretion was nearly equal each day. In comparison with the urinary excretion of 1 day of multiple oral dosing, here, a slightly larger amount of the unchanged drug was excreted daily. Table 2 shows the results of laboratory tests of volunteers before and after drug administrations. These subjects showed normal laboratory values. No side effect was seen during these experiments.

\section{Discussion and Conclusion}

Some knowledge of pharmacokinetic data for single and multiple oral dosing is necessary to develope an optimum dosage schedule which would balance patient convenience with proper body content of drug. In the present investigation, the peak plasma levels of cinepazide were observed at $1-3 \mathrm{hr}$ following single oral doses. Oliver, M. C. et al. (1977) reported that the peak plasma level of cinepazide occurred at $30 \sim 45$ min following a single $200 \mathrm{mg}$ oral dose in the fasting state. The difference might be due to the gastric emptying rate. The variation in plasma levels at $0.5-1 \mathrm{hr}$ could also be related to variability in the onset of absorption among 
Table 7 Urinary Excretion of Unchanged Cinepazide during and after Multiple Oral Administration to Human Subjects $(200 \mathrm{mg}$, t. i. d., for one day)

\begin{tabular}{c|r|r|r|r|l}
\hline \multirow{2}{*}{ Subject } & \multicolumn{5}{|c}{ Excretion in urine (mg) } \\
\cline { 2 - 6 } & $0 \sim 4$ & $4 \sim 8$ & $8 \sim 24$ & $24 \sim 32$ & $0 \sim 32(\mathrm{hr})$ \\
\hline $\mathrm{A}$ & 77.4 & 88.6 & 106.4 & 5.0 & 277.4 \\
$\mathrm{~B}$ & 82.9 & 149.6 & 179.2 & 3.1 & 414.8 \\
$\mathrm{C}$ & 77.3 & 89.8 & 79.1 & 4.9 & 251.1 \\
$\mathrm{D}$ & 78.8 & 128.9 & 138.4 & 7.9 & 354.0 \\
$\mathrm{E}$ & 51.1 & 134.5 & 151.5 & 5.8 & 342.9 \\
$\mathrm{~F}$ & 65.7 & 99.5 & 127.5 & 8.5 & 301.2 \\
$\mathrm{G}$ & 86.4 & 123.7 & 130.0 & 4.0 & 344.1 \\
\hline \multirow{2}{*}{ Mean \pm S.E. } & 74.23 & 116.37 & 130.30 & 5.60 & 326.50 \\
& \pm 4.55 & \pm 9.00 & \pm 12.06 & \pm 0.75 & \pm 20.63 \\
\hline Accumulated & 74.23 & 190.60 & 320.90 & 326.50 & 54.42 \\
mean value & \pm 4.55 & \pm 10.07 & \pm 20.84 & \pm 20.63 & $\begin{array}{c} \pm 3.44 \\
\pm \text { S.E }\end{array}$ \\
\hline
\end{tabular}

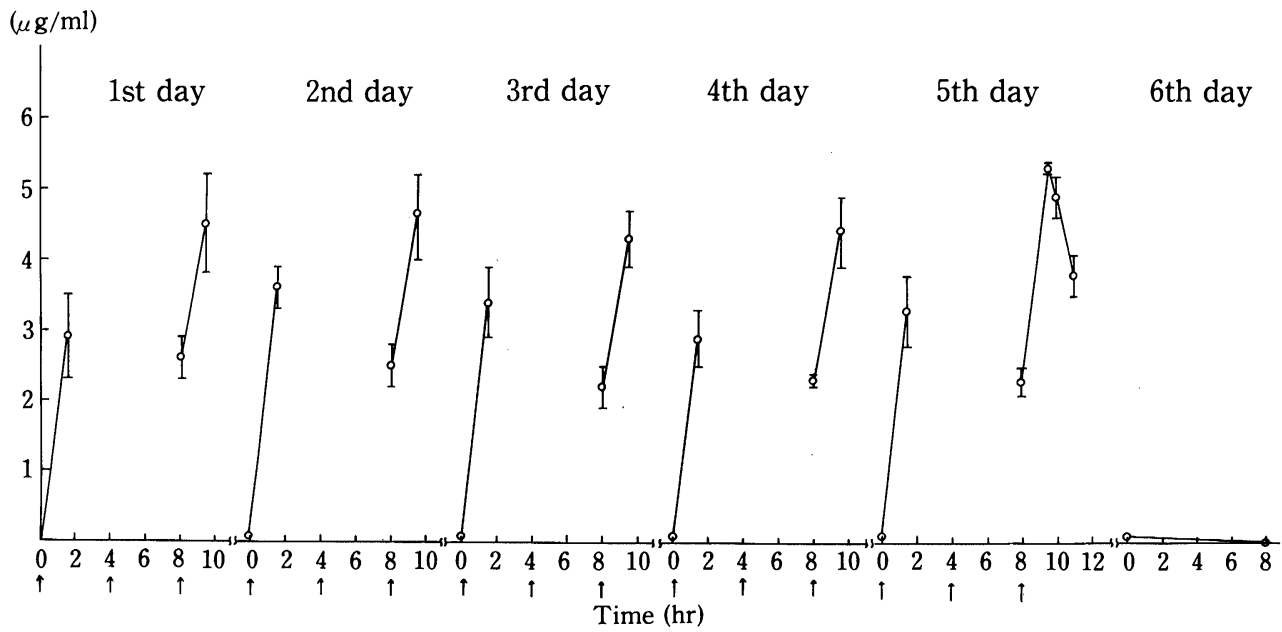

Fig. 5 Mean plasma level of unchanged cinepazide during and after multiple administration $(200 \mathrm{mg}$, t. i. d., for five days). Mean \pm S. E. are given.

volunteers, because of malabsorption of cinepazide (basic drug) in the stomach. Of practical importance is the fact that the presence of food appeared to delay the absorption of cinepazide. The peak plasma level increased proportionally with the therapeutic dose of cinepazide. In the multiple dose study, peak and valley plasma cinepazide levels were predicted using a com- puter program describing an one compartment, open linear pharmacokinetic model. Correlation between the assayed and the computerpredicted median values was 0.964 after 1-day dosage ; with 5 day dosage, the correlation was 0.981 . The results indicated that plasma cinepazide concentration-time profiles following p.o. doses of the drug could be represented by a 
Table 8 Urinary Excretion of Unchanged Cinepazide during and after Multiple Oral Administration to Human Subjects ( $200 \mathrm{mg}$, t. i. d., for 5 days)

\begin{tabular}{|c|c|c|c|c|c|c|c|}
\hline \multirow{2}{*}{ Subject } & \multicolumn{7}{|c|}{ Excretion in urine $(\mathrm{mg})$} \\
\hline & 1 & 2 & 3 & 4 & 5 & 6 & $0 \sim 6$ (day) \\
\hline $\mathrm{A}$ & 291.6 & 349.4 & 309.7 & 303.6 & 216.3 & 4.0 & 1474.6 \\
\hline $\mathrm{B}$ & 414.9 & 428.8 & 429.5 & 379.9 & 346.7 & 5.4 & 2005.2 \\
\hline $\mathrm{C}$ & 253.4 & 305.0 & 317.5 & 307.0 & 297.5 & 3.6 & 1484.0 \\
\hline $\mathrm{D}$ & 257.9 & 453.8 & 421.6 & 437.6 & 313.5 & 7.5 & 1891.9 \\
\hline $\mathrm{E}$ & 436.8 & 461.7 & 485.5 & 422.6 & 369.6 & 5.8 & 2182.0 \\
\hline $\mathrm{F}$ & 386.8 & 330.5 & 398.0 & 438.2 & 280.1 & 5.3 & 1838.9 \\
\hline G & 470.0 & 447.0 & 452.8 & 419.8 & 320.6 & 4.7 & 2114.9 \\
\hline \multirow{2}{*}{ Mean \pm S.E. } & 358.77 & 396.60 & 402.09 & 386.96 & 306.33 & 5.19 & 1855.93 \\
\hline & \pm 33.87 & \pm 24.92 & \pm 25.06 & \pm 22.32 & \pm 18.75 & \pm 0.49 & \\
\hline \multirow{2}{*}{$\begin{array}{c}\text { Accumulated } \\
\text { mean value } \\
\pm \text { S.E. }\end{array}$} & 358.77 & 755.37 & 1157.46 & 1544.41 & 1850.74 & 1855.93 & \\
\hline & \pm 33.87 & \pm 51.09 & \pm 74.67 & \pm 92.11 & \pm 106.74 & \pm 107.02 & \\
\hline \multirow{2}{*}{$\begin{array}{l}\text { Accumulated } \\
\text { mean per cent } \\
\text { of dose } \pm S . E .\end{array}$} & 59.80 & 62.95 & 64.30 & 64.35 & 61.69 & 61.86 & \\
\hline & \pm 5.65 & \pm 4.26 & \pm 4.15 & \pm 3.84 & \pm 3.56 & \pm 3.57 & \\
\hline
\end{tabular}

linear pharmacokinetic system with reproducible absorption. This multiple dosing schedule using the same dose $(200 \mathrm{mg}$ every $4 \mathrm{hr}$ for three doses) produced a peak level at $4.7 \mu \mathrm{g} / \mathrm{ml}$ after the $3 \mathrm{rd}$ administration, falling to barely measurable quantities prior to the next day's dose. The total excretion in the urine was 115 and $267 \mathrm{mg}$ during $24 \mathrm{hr}$ collection period for the 200 and $400 \mathrm{mg}$ single doses, respectively. The extent of urinary excretion was larger than that reported by Oliver, M. C. et al. (1977).

The extent of urinary excretion of cinepazide increased slightly with increased dosing. This tendency might be due to the slow metabolism of cinepazide at higher dose. The cumulative urinary excretion of cinepazide was nearly constant during the experiments. This result suggested reproducible absorption and excretion of cinepazide during multiple dose experiments. The experimental results presented here show that the urinary excretion rate of unchanged cinepazide is directly proportional to the plasma level in human subjects. It thus would appear that plasma cinepazide was mainly excreted in the urine without significant transformation.

In conclusion, cinepazide is well-absorbed orally. The onset of absorption is delayed by food. Cinepazide is mainly excreted in the urine as the intact compound. The peak plasma level of cinepazide is dose dependent in the therapeutic dose range. Urinary excretion of unchanged cinepazide is slightly larger in higher doses. No difference is observed in the plasma -level and urinary excretion patterns during the ordinary dosage schedule (200 mg t.i.d.). No accumulation of the drug and no side-effect are expected following repetitive oral dosing in the clinical trials.

\section{Acknowledgement}

The authors thank Dr. Y. Yoshii, director of the Daiichi Seiyaku Medical Office, for the blood and urine sampling. 


\section{References}

Bremer, C: Wirkung eines neuen Arzneimittels bei peripheren angiopathien im gekreuzten Doppel-blindversuch. Med. Welt., 25 : 17701773 (1974).

Cameron, B. D., Chasseaud, L. F., Hawkins, D. R. et al.: The metabolic fate of the coronary vasodilator 4-(3, 4, 5-trimethoxycinnamoyl)-1(N-pyrrolidinocarbonylmethyl)piperazine (cinepazide) in the rat, dog and man. Xenobiotica, 6 : 441-445 (1976).

Fauran, C. and Jurin, M. : Cinnamoyl-4-piperazineacetates and acetamides with coronary-dilating activity. I. Synthesis. Chim. Ther., $4: 290-$ 292 (1969).

Garrigues, A. : Essai clinique du Vasodistal dans le traitement des artériopathies chroniques des membres inférieurs. Méd. Praticienne., 583 : avril (1975).

Huguet, G., Raynaud, G. and Pourrias, B. : NPiperazinyl cinnamoylamides with coronary dilating activity. II. Pharmacological study. Chim. Ther., 4 : 293-297 (1969).

Lowenthal, W. and Vitsky, B. L. : Computer program for a double exponential equation to determine biological constants. J. Pharm. Sci., 56 : 169-173 (1967).

Marmo, E., Caputi, A. P. and Cataldi, S. : Experimental investigation of 4-(3, 4, 5-trimethoxycinnamoyl)-1-piperazinyl pyrrolidinyl maleate : effect on the cardiovascular system and on certain smooth muscles. Farmaco [Prat.], $28: 132-160$ (1973).
Mueller, F. W. and Lieverman, S. V. : Fitting a double-exponential curve to observed salicylate concentrations in blood. J. Pharm. Sci., 59 : 514-517 (1969).

Nomura, H., Tsumura, M., Takasugi, N. et al. : Metabolism of the vasodilator 4-(3, 4, 5-trimethoxycinnamoyl)-1-(1-pyrrolidinyl)carbonylmethylpiperazine maleate (cinepazide). Isolation and identification of metabolites in rat and man. J. Pharm. Dyn., in press.

Oliver, M. C. and Rabiant, J. : Excretion urinaire et taux plasmatiques du chez l'Homme. Ann. Pharm. Fr., 35 : 265-273 (1977).

Pourrias, B., Bouvet, P. and Raynaud, G. : Etude pharmacodynamique d'un nouveau vasodilatateur, le maléate de cinépazide. I.-Action vasodilatrice. Therapie., $29: 29-41$ (1974).

Pourrias, B., Bouvet, P., Raynaud, G. et al. : Etude Pharmacodynamique d'un nouveau vasodilatateur, le maleate de cinépazide, II.-Action sur l'hemodynamique genérale et cardiaque, la respiration et la diurése. Therapie., $29: 43-50$ (1974).

Tsumura, M., Nomura, H., Yamada, M. et al. : Metabolism of 4-(3, 4, 5-trimethoxycinnamoyl) -1- (1-pyrrolidinyl) carbonylmethylpiperazine maleate (cinepazide), a new vasodilator (1) Absorption, distribution, excretion and metabolism in rats., (2) Absorption, distribution, excretion and metabolism after multiple administration in rats and placental transfer and excretion in the milk of rats and mice. Oyo Yakuri, in press. 